\title{
Ideology in the Translation of Political Speeches during the Arab-Israeli Conflict: A Critical Discourse Analysis
}

\author{
Husam Haj Omar, \\ University of Oxford
}

\section{Introduction}

Equivalence no longer governs the production and reception of translation (Hatim and Munday 200). Translation is not merely an innocent transfer of ideas from one language into another. This study views translation as a process that can be ideologically manipulated to influence perceptions and undermine the target culture. This paper investigates the influence of ideology on the translation choices made by the translators and the patrons represented by media outlets in translating political speeches during the two Israeli offensives against Lebanon, 2006 and Gaza, 2008/9. Both offensives were launched by Israel against two parties which have a similar ideology, namely Hezbollah in Lebanon and the Hamas authority in the Gaza Strip. Both adopt an anti-Israeli Islamist ideology, and both are known to be backed by Iran. This study aims to analyze the translations of political speeches by Hezbollah and Hamas leaders, and it proposes that the translations conducted by Western and Israeli translators working for Western and Israeli outlets are influenced by the ideological agenda of their employers, i.e. the media channels they work for. The same applies to translations produced by media outlets that represent and/or support Hamas and Hezbollah. A detailed explanation of the corpus will be provided in the methodology and corpus section. Critical Discourse Analysis and the theories examining the roles played by the translator, firstly as a reader and secondly as an author of the target text, constitute the main theoretical foundation of the study in addition to the concept of patronage which plays a crucial factor in determining the outcome of the translation process.

This paper consists of seven main sections. The first is an introduction to the study. The second examines the definition and aspects of ideology in relation to other concepts of power, culture, and politics. The third focuses on ideology in discourse; ideological strategies and tools are listed to highlight how ideology operates within language and through media. The fourth section discusses ideology in translation, shedding light on the impact of the translator's ideology and the patrons' interests on the translation, in addition to the roles the translator takes accordingly as reader of the source text (ST) and author of the target text (TT). Thereafter, the focus shifts to the notion of mediation, and then to the way ideological strategies are employed in translation. The fifth section explains the methodology used in the study and the corpus selection process. The sixth section is devoted to analyzing the data derived from two specific Arab-Israeli conflicts: the 2006 Lebanon war and the 2008/9 Gaza war. The paper is concluded with a seventh section that discusses the findings of the study. 


\section{Thinking Ideology}

In the last century, ideological movements such as communism, socialism, and nationalism emerged to counter colonization and capitalism. After the Islamic revolution in Iran, Islamism emerged in the Muslim World and has become the mainstream opposing and resisting the New World Order formed and led mainly by the USA following the collapse of communism in the Soviet Union (Huntington). The following extract serves as a manifestation of this attitude:

On April 18, 1994 two thousand people rallied in Sarajevo waving the flags of Saudi Arabia and Turkey. By flying those banners, instead of UN, NATO, or American flags, these Sarajevans identified themselves with their fellow Muslims and told the world who were their real and not-so-real friends. (Huntington 19)

Although Americans and Europeans played a major role in the liberation of Bosnia, this act of identification and identity-demonstration by the Sarajevans represented an aspect of the new-born ideological conflict. The Sarajevans expressed their loyalty and gratitude to the Turkish and Saudis with whom they shared the same culture, religion, and most importantly ideology.

The definition of ideology evolved with theorists giving it numerous definitions beyond its general description as a set of beliefs, dispositions, and habits (Raymond 5). Karl Marx gave 'ideology' its political connotation: "The ideas of the ruling class are in every epoch the ruling idea" (Marx and Engels 64). Marx sees ideology as an illusion which provides a false vision of reality. He views it as temporary, something that vanishes once the power or the class system that has imposed it collapses. Marx believes that a classless system will emerge after the working class demolishes capitalism (Marx and Engels 64).

Van Dijk (48-49) defines ideology as "the set of factual and evaluative beliefs-that is the knowledge and the opinions of a group". He seems to agree with Verschueren (vii):

Ideology is interpreted as any constellation of beliefs or ideas, bearing on an aspect of social reality which are experienced as fundamental or commonsensical and which can be observed to play a normative role.

The Oxford English Dictionary (OED) refers to ideology, in its broadest sense, as a set of beliefs held by a specific group that influences the way people behave. Therefore, it may cover a wide range of domains: political, social, ethical, religious, and so on. Nevertheless, ideology is often associated by the majority of people with the negative sense of politics and the dominant radical power in society. Eagleton (30) argues that ideology is a means of legitimation used by the ruling force or class in society; this legitimation can be achieved through ideology by either "distortion or dissimulation" (Eagleton 30). Ideology, however, might be viewed from a more positive perspective as it can be considered as a carrier of values of a certain group. Ideology governs, by necessity, all societies and can constitute a framework of people's ideas and beliefs away from the radical vision. This paper adopts the definition 
of ideology as explained in the OED. It considers the role played by ideology in translation as a negative factor leading to manipulation and falsification of the message intended by the creator of the source text, admitting at the same time that the influence of ideology is inevitable and unavoidable, especially in the translation of political discourse.

\section{Ideology in Political Discourse: Strategies and Tools}

Ideology, power, and politics co-exist, interact, and operate together. Political organizations, whether in power as in governments or seeking power as in lobbyists, propose ideologies that make their interests seem to be in everybody's interests. They tend to promote their beliefs and values by naturalizing and universalizing them, so that they can influence people to believe in their ideas (Yahiaoui 7-8). The Egyptian media during the days of the late Egyptian President Gamal Abdel AlNasser serves as an example: Nasser's media had the upper hand in the Arab World and strongly influenced the Arab people, spreading the Pan-Arabist ideology across Arab countries.

Due to its interaction with power, politics takes an exclusionary form and constitutes the main arena of conflict between rival ideologies. Governments tend to employ the media to exclude any ideas that may undermine the foundations of their authority (Van Dijk). The Soviet Union, for instance, spread communism across the Union and Eastern Europe, eradicating nationalistic notions from the political arena in the region. The concept of exclusion of rival ideologies manifests itself through positive self-presentation and negative other-presentation (Van Dijk 69) as well as through the two principles of legitimation and delegitimation. Each political group promotes its principles as just and universal, claiming that they represent common sense. On the other hand, opponent ideologies are presented as party-centred and self-serving while the negative aspects of their discourse are highlighted (Van Dijk 258-61). Accordingly, one's own positive statements and decisions are maximised while the others' positive statements and actions are minimized. Similarly, one's own negative statement and actions are minimized and the other's negative choices and policies are maximized (Van Dijk 67).

The Palestinian President Mahmoud Abbas, in a speech delivered in the city of Jenin on 13 October 2009, declared:

$$
\begin{aligned}
& \text { همنا الأعظم هو استعادة وحدتنا الوطنية، و إنهاء الانقلاب الأسود الذي وقع في قطاع غزة، و إنهاء الظلادمية، }
\end{aligned}
$$

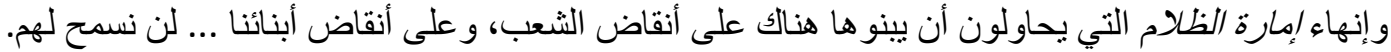

$$
\begin{aligned}
& \text { نحن طلاب وحلة وطنية (Abbas). }
\end{aligned}
$$

[Our major concern is to retain our national unity; to put an end to the black coup that took place in the Gaza Strip; to end obscurantism; to end the obscurantist Emirate that they are trying to establish on the remains of the people and our sons ... We will not allow it. We are seeking national unity.]

On the one hand, Abbas employs negative other-presentation to undermine the legitimation of Hamas, which took over power in the Gaza Strip on 14 June 2007, using expressions with culturally and ideologically negative associations such as black coup, obscurantism and obscurantist Emirate to describe 
Hamas' practices and approaches in Gaza. On the other hand, he draws a positive image of his party, promoting their principles by claiming that they are "seeking national unity" (Abbas).

Phillipson points out three political as well as ideological techniques used in Western media that reveal the sense of superiority adopted by decision makers in the West. The first is portraying the Oppressor, as democratic, liberal and civilized. The second is undermining the primitive Oppressed, that is likely to belong to an Eastern developing country by claiming that it lacks reform and guidance. The third is presenting the relationship between the Oppressor and the Oppressed as a big brother relationship in which the oppressor is entitled to guide and give advice to their younger brother, the oppressed.

If presented explicitly, ideology in discourse cannot be effective. The receiver is supposed to interpret the discourse and absorb the invisible ideological assumptions embedded in it; otherwise, ideology ceases to be "common sense" (Fairclough, Language and Power 84-85). The way to reach the level of common sense is to naturalize the discourse through several strategies and processes, such as the constant repetition of ideology-based false claims and establishing a link between people's lifestyles and expectations and ideological messages in a discourse in a way that normalizes the ideology in the long run.

Roger Fowler (1-2) argues that for a piece of news to be published it needs to undergo a process of selection according to certain criteria set by the publishing institution. Then, it passes through another process of transformation. Transformation may involve both representation (choice of lexis and structure) and evaluation (a reporter's comments on a piece of news). Similarly, Kress and Hodge (157) argue that media institutions can follow two strategies of "manipulation". First, they may manipulate reality by representing both the events and people involved in the incident. Second, they may manipulate the orientation to reality through a process of evaluation.

Another scholar who tackles the ideological strategies adopted by media outlets is Abdullah Shunnaq (Monitoring and Managing in the Language of Broadcasting and Newspaper). He bases his argument on two of the strategies suggested by Hatim and Mason (Discourse and the Translator). The media institution may merely monitor the event by describing it transparently. It may, however, manage the news by "steering" the situation in line with its own agendas. Media institutions for Shunnaq (122) resort to certain procedures to manage their news. Firstly, they report news which serves their own purposes only. Secondly, they tend to vaguely describe certain stories to avoid the receivers' shock. Thirdly, they may uncover the agents of reported action. Fourthly, they interfere by adding to the original text, using expressions that have certain connotations. The purpose could be either to heighten the emotiveness or to reduce the impact on receivers. Shunnaq's monitoring can be compared to Fairclough's notion of direct reporting. Fairclough (Analysing Discourse: Textual Analysis for Social Research 49) suggests that direct reporting contains a degree of faithfulness since it aims to "reproduce what was actually said or written" unlike indirect reporting which may involve manipulation. In any case, it is impossible for the media to be neutral when ideology is involved. 
Fowler points out certain ideological tools utilized in media discourse to achieve the strategies mentioned earlier: consensus, stereotypes, conversational style, and terms of abuse and endearment. Media tends to promote the assumption that there is often a consensus of opinion concerning a matter of national or ideological nature (Fowler 48). For instance, the chant labbayka ya Nașralla (literally, "at your service, Nasrallah"), which Nasrallah's supporters repeat during his live speeches, has been heavily quoted and frequently reported in Hezbollah's media institutions to suggest a popular consensus in support of Hezbollah. Media, moreover, may categorize people and events in cognitive frames, stereotypes or what Fowler calls "pigeon-holes" (Fowler 17). An article published in Ammon News under the title, "Al'Orüba.. Bayna Salāh Ad-Din Wa Ardugan” ("[Arabism, between Saladin and Erdogan]”) (Al-Majali) serves as an example. Owing to his solid stand against Israel, the Turkish Prime Minister, Erdogan, is framed by the writer Sahar al-Majali, as Saladin with all the ideological connotations associated with this figure in Islamic history and the Arab region. Conversational style is used sometimes in media to create an atmosphere of familiarity and informality between a media institution and the audience to pass a certain ideology into the receivers (Fowler 57). Finally, terms of abuse and endearment can be employed to approach the audience and promote a certain ideology (Fowler 117). In accordance with this tool, negative attributes are used in the discourse to attack the opponent while positive ones are used to glorify the self.

\section{Ideology in Translation}

The ideological influence on translation is as old as translation itself. Fawcett (107) states: "throughout the centuries, individuals and institutions applied their particular beliefs to the production of certain effect in translation." Ideology governs every aspect of human life, and translation is no exception. In fact, it is impossible to extract the ideology from the text and the text from the ideology; they are indeed intertwined. The point of focus in translation analysis has shifted towards the role of agency, with ideology in its various aspects being the factor that determines the outcome of the translation process. Agents select the text to be translated in line with certain agendas. Schäffner ("Third Ways and New Centres: Ideological Unity or Difference?" 23) claims that "the choice of a source text and the use to which the subsequent target text is put are determined by the interests, aims and objectives of social agents."

The lack of attention paid to the social aspects of translation led to the launch of Critical Discourse Analysis (CDA) as a method of research which explores "the ideological forces that underlie communicative exchanges" (Calzada-Pérez 2). Fairclough defines Critical Discourse Analysis (CDA) as an interdisciplinary approach to the study of discourse. He also uses the term talk and text that views language as a form of social practice to describe CDA. Accordingly, "(non-linguistic) social practice and linguistic practice constitute one another and focus on investigating how societal power relations are established and reinforced through language use" (Fairclough Critical Discourse Analysis: The Critical Study of Language 87). Jan Blommaert and Chris Bucaen (451) distinguish CDA from discourse analysis in that CDA highlights "issues of power asymmetries, manipulation, exploitation, and structural inequities" in domains such as education, media, and politics. 
CDA theorists argue that language itself is ideological; therefore, translation constitutes a main field for ideological encounters. Translation may become an act of manipulation and a process of rewriting of the source text in which the translator's intention and ideology manifest themselves "in the service of power" (Venuti The Translator's Invisibility vii). So, who translates, why and with what aim in mind are all questions that need to be asked and addressed when considering the outcomes of the translation process (Lefèvere, Translation/ History/ Culture 1). As an interpreter of the original text and a producer of the target text, a translator controls the outcome of the translation process and can steer it in accordance with their personal ideology and their patrons' agendas.

\subsection{Ideology and Translator's Role as Reader}

According to Structuralists, language is a system of signs in which a sign is the outcome of the relationship between a signifier and a signified. Roman (310) asserts that signifiers are not "fixed" or "unchangeable"; therefore, the outcome of the relationship between the signifier and the signified changes along with the change of readership. The meaning that a chain of signs takes differs from one reader to another. This assumption has shifted the way of perceiving language with all its aspects, including translation.

The text, for Barthes, is to be read in an intertextual context; it is to be viewed in line with other texts (quoted in Hermans 69). In other words, a translator interprets the text in accordance with their previous knowledge (words, phrases, statements and conventions), which is not only linguistic and encyclopaedic, but also ideological. The consequence will be the metaphorical death of the author and the end of its role as a sole producer of the text (quoted in Hermans 69). The original text itself is an outcome of a transformation process from ideas to written words. When this chain of words is rendered into a different language, the process becomes even more complicated. Thus, the faithfulness to the source text is compromised (Venuti, Rehinking Translation 98).

The author's intention may not be carried over by the translator whose understanding of the source text is governed by their ideology. The translator is subject to social and/or ideological factors; and the translator's interpretation of the source text is, accordingly, subjective and cutluralized. In support of this argument, Robinson defines translators as "those people who ... let their knowledge govern their behaviour" (84). He views this "knowledge" as "ideological" (84).

\subsection{Ideology and the Translator's Role as Author}

Although the translator, in theory, is supposed to respect the intention of the author of the source text, the translator often turns to an author who rewrites the target text, ultimately determining the outcome of the translation process as a new independent product with unique characteristics. Lefèvere (Translation, Rewriting and the Manipulation of Literary Fame 13) was the first to view translation as reproduction and rewriting. He perceives it as a process influenced by various systems and norms of a society, namely ideology and patronage. Translators might not limit themselves to the mission of producing a mirror image of the source text. They are in a position to manipulate the source text and come up with a target text that is consistent with certain ideological agendas. Schäffner ("Skopos 
Theory" 236) sees the translator as a master who has everything in their hand; translators free themselves from all restrictions of loyalty, faithfulness and originality.

For instance, an East-oriented source text, for a Western audience, might bear an "exotic discourse" which "can be manipulated" by the translator "to such an extent as to conceive it" as "an invented geography, an imaginary space built according to the ideology, cultural values and norms of the West" (Álvarez and Vidal 3). Many international media outlets, for example, tend to translate the Arabic Islamic term Jihad into English as Holy $W$ ar which bears terrifying, extremist and violent implications for a Western audience. Thus, these outlets embrace only one interpretation of the complex SL term, ignoring other social and non-violent interpretations which include, and are not limited to, treating people well despite their misbehaviour, and making every effort to avoid committing sins. Such a translation choice, thus, contributes to distorting the image of Islamic values and traditions.

Translators find themselves with the authority to adjust the source text in order to match a desired model with a view to achieve acceptance within a certain society. In this sense, the source text undergoes a process of undermining the Other and their ideas in line with a personal motive, perhaps ideological (Álvarez and Vidal). At the centre of this process are the translator's attitudes, misconceptions held about the Other's language and culture, and their ideological, particularly political and religious, convictions. Thus, the translator cannot be conceived as a neutral mediator between the source and targets texts (Haj Omar). In brief, the translator plays an active and dominant role in two processes: the reading and rewriting of the source text.

The name of the Gulf, for instance, constitutes a political minefield for translators as it creates a controversy between the Arabs, who refer to it as the Arabian Gulf, and the Iranians, who favour the name, the Persian Gulf. Thus, a translator would often choose to use the name in accordance with the ideology they embrace and national background they have. The same may apply to the name of the arm of the Atlantic Ocean that separates Great Britain from northern France. While the English like to call it the English Channel, the French adopt the name, la Manche. Although the translator tends to extend their ideological views over the target text, translators often abide by the agenda set by the institution behind the production and publication of a given translation. This leads us to exploring the role played by patrons in determining the outcome of the translation process.

\subsection{Translation and Patrons}

Translations are often chosen and reviewed by agents in line with ideological, economic, social or cultural considerations. Certain parameters and guidelines dictated by patrons, including publishers, editors and institutions, govern the translator's work. Hence, the whole operation is aimed at implementing the patrons' scheme and establishing their legitimacy over the entire process. Thus, "translation needs to be studied in connection with power and patronage, ideology and poetics with emphasis on the various attempts to ... undermine an existing ideology" (Lefèvere, Translation/ History/ Culture 10). The translator is often obliged to address the tyranny of a dominant culture that considers 
itself superior, especially if they translate into the language of this culture. Lefèvere cites Hender on the French translations of Homer: "Homer must enter France a captive and dress according to their fashion, so as not to offend their eyes" (Translation/ History/ Culture 70).

Nevertheless, the contract between the translator and the patron may turn to a clash between the translator's own beliefs and the patron's agendas. History witnessed many attempts by translators to challenge the patrons' censorship. One example is Étienne Dolet whose translation of the Bible into French brought him in confrontation with the authorities: he was arrested, convicted of heresy and then executed (Yahiaoui 27).

Translation in the political sphere is largely affected by the decisions of the people in power. Governments, policy makers and publishers work at a level higher than that of translators, authors and editors. They tend to control the translation process in order to keep it in line with their own ideologies. For instance, the translation activity from Greek and Latin into Arabic under the rule of the Abbasids, especially the seventh Abbasid caliph Al-Ma'mun, was selective. Translators followed the will of the rulers who were most interested in translating the scientific and military works, avoiding philosophy due to religious ideological restrictions. Turkey serves as another example of patrons' control over translation. After the collapse of the Ottoman Empire and the emergence of the modern Turkish state, the movement of translation from European languages flourished, and the state renounced the use of Arabic letters as the alphabet of Turkish, adopting the Roman alphabet instead (Tahir-Gürçağlar 114). This was because the Arabic alphabet was a symbol of the Islamic heritage, which was viewed as an obstacle in the face of the development of the new Turkey.

\subsection{Translator and Objectivity: Ideological Strategies}

As suggested in the previous sections, a translator's choices are often governed by their previous knowledge, which is naturally derived from their cultural heritage and social conventions. This produces various kinds of pressures, which either allow their subconscious mind to govern the translation process or make them surrender to their consciousness, exposing the target text to various ideological, cultural and economic influences. Shunnaq ("Monitoring and Managing in Radio News Reports" 104) argues against the assumption that the translator is morally bound and should be, therefore, neutral. For him, this is unrealistic and an extreme oversimplification of the issue. It "suppresses" the translator's "natural feelings" (104). Long experience in practical translation proves that ideological and natural considerations are superior to the translator's objectivity.

The impact of ideology on the target text may come from three sources: the author, the translator, and the reader of the target text. In line with this proposition, Kaiser-Cooke differentiates between two types of translators: novice and expert translators. Being aware of the author's intention and the receivers' expectations, expert translators make their choice between foreignization and domestication accordingly (Venuti, "Strategies of Translation"). Therefore, the translator cannot be completely objective when they are under the burden of the patrons' pressure, the receivers' 
expectations, and their own ideology. This does not allow the translator to convey the message intended by the author.

This argument brings the concept of mediation into light. Some scholars view mediation from a positive perspective. For Neubert ("Translation, Interpreting and Text Linguistics" 141), mediation "means the opposite of prominence"; it is a way of "keeping a balance" between the sender and the receiver, a means to "understand the other" and achieve "agreement" (141). However, he admits that "the main traits of the translator's personality" can be traced throughout the target text as the translator is essentially a "mediating agent" aiming at a "mediating effect" (Neubert, "Translation as Mediation" 7). Hatim and Mason, however, argue that through mediation, translators "intervene" in the process, imposing their own ideology over the text (The Translator as Communicator 122). Mediation can be minimal, partial or maximal and is manifested by the employment of four main tools: cohesion, transitivity, lexical choice and style-shifting. Minimal and maximal mediations are comparable to Venuti's two notions of foreignisation and domestication respectively; partial mediation lies somewhere in the middle. Hatim and Mason's approach deals with mediation as a process through which the translator makes fundamental changes to the source text to match their own ideology (The Translator as Communicator 119). This paper proposes that when ideology is involved, the translator as a mediator tends to domesticate the target text, by maximizing their intervention in the translation process resulting in changes that correspond to the ideology which they aim to promote. This can be done by the employment of several translation strategies and procedures.

It is argued that managing (as opposed to monitoring), which can be found in various names in Translation Studies, is the main ideological strategy employed in translation. Farghal distinguishes between two types of managing: intrinsic and extrinsic (quoted in Shunnaq, "Monitoring and Managing in Radio News Reports" 104). The first indicates alterations that aim to sort "mismatches" between the source and targets texts while the second results from the adjustment to the "message" of the target text by the translator to achieve certain ideological purposes (quoted in Shunnaq 104). Similarly, Ghazala points out two types of bias: negative bias which underlies changing certain aspects in the source text to fulfil personal wishes on the translator's side such as "ignorance, hypocrisy or discrimination"; and positive bias which refers to the translator's "justifiable acts" aimed at explaining ambiguities, correcting errors or omitting trivial and taboo expressions (155-58). According to Ghazala, culture itself is biased, so "one cannot expect but a biased translator" (147). On the one hand, if the translator finds a cultural equivalent in the target language, they acculturate it. On the other hand, if the cultural reference is translated literally, they ambiguate it (Ghazala 148-49). Any decision a translator makes is necessarily subjective and naturally biased to the culture they belong to.

\section{Methodology and Corpus}

This study is a qualitative research study which uses Critical discourse analysis (CDA) as a methodology to conduct a vigorous assessment of the translation choices made by translators and authorized by their media outlets. Samples of translations have been selected for this study, and the aim is to detect the role of ideology in shaping the translation choices. The rationale behind the selection of data is for the translations to be representative of all parties involved and interested in the conflicts: namely, anti- 
Israeli media, pro-Israeli media and Western media. The purpose is to produce objective results that reflect the role of ideology in the media reporting of the carefully selected translations of speeches.

The two Israeli offensives against Lebanon, 2006 and Gaza, 2008/9 are similar in some respects, and that is why these two events and the way they were reported by the media outlets have been chosen as illustrative cases for this study. First, both offensives were initiated by Israel against two parties that have common ideological grounds-Hamas and Hezbollah, since both adopt an Islamist Ideology and constituted, along with Syria and Iran what was claimed as an anti-Israeli front. The two conflicts lasted for approximately a month resulting in hundreds of fatalities amongst civilians. Most importantly, the political statements produced by Hasan Nasrallah, Hezbollah Secretary General, and those of Hamas' leaders, Ismail Haniyeh and Khaled Mashal, had a lot of similarities in form and content; the three leaders addressed their supporters in a state of war, urging them to resist what they considered an aggression, while promising them victory on many occasions.

News sources address different audiences with different ideologies and political backgrounds. During these conflicts, the political discourse of Hezbollah and Hamas was translated, interpreted and reported differently by various news agencies, channels and websites in line with their own ideologies and political stances. Hence, the role of agents and patrons is highlighted in this study. The data corpus consists of written news reports and articles with translated excerpts of the statements of (a) Hasan Nasrallah, Hezbollah Secretary General, (b) Khaled Mashal, the then Head of Hamas Political Bureau, and (c) Ismail Haniyeh, the then Hamas Prime Minister in Gaza, during the two conflicts. Additionally, some audio-visual materials are used or referred to in the study. The sources of the translations fall into three main categories. The first is Arab-owned media represented here by Aljazeera English which is strongly anti-Israeli. The second is Western media represented here by CNN, The Telegraph and Fox News, which generally expressed pro-Israeli views during the offensives, and considered Hamas and Hezbollah terrorist organizations. The third is Israeli and/or Israeli ideologically affiliated media represented by The Jerusalem Post, Memri and Ynet News. The following section is devoted to analyzing the data specified.

\section{Data Analysis}

In the Middle East, the gun and the dictionary march hand in hand (Suleiman 11). Abdullah Shunnaq ("Monitoring and Managing in Radio News Reports" 104) argues that the translator cannot be neutral or suppress their "natural feelings" (104). Steered by what seems to be the ideological and political agenda of their patrons and/or those of their own, some Western media news outlets lacked objectivity in their presentation and translation of the political discourse of the Hamas and Hezbollah leaders during the two Israeli offensives. In an interview with Aljazeera on 21 July 2006, Nasrallah said:

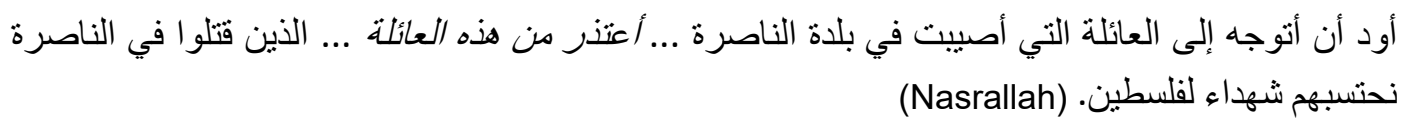


[To the family that was hit in Nazareth ... I apologise to this family ... We consider those who were killed in Nazareth martyrs for Palestine.]

However, the title of a report on Nasrallah's interview published on the CNN website ("Hezbollah Leader Apologizes for Attack's Child Victims") can be misleading as two main interventions made during the translation/reporting process can be traced. First, the title creates a deliberate sense of ambiguity by not specifying to whom the apology is made. It may hence give the impression that Nasrallah apologizes for the killing to Israel, which is not precisely true as Nasrallah clearly apologizes only to the Arab family that was hit by the attack. The deletion of this important element in Nasrallah's statement results in distortion in meaning. Second, the report, by referring to "child victims" in its title, adds information that does not exist in Nasrallah's statement. The source text only includes the term al- 'a'ilah "the family". This addition may be aimed at criminalizing and delegitimizing Nasrallah and his militia and attracting the target reader's sympathy towards Israel.

On many occasions during the two offensives, news outlets seem to have interpreted the Hamas and Hezbollah leaders' political statements in line with previously acquired knowledge (words, phrases, statements and conventions), which was ultimately ideological. This often resulted in the original speaker's intention not being always preserved by the translator. An example comes from a report published on The Jerusalem Post website, which looks at a speech by Nasrallah aired on Al-Manar TV on 14 July 2006:

\section{Nasrallab's Statement}

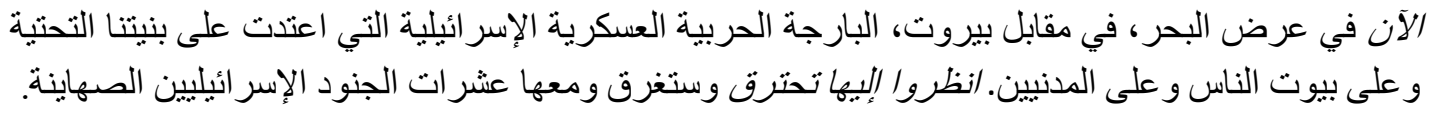

[Now at sea, opposite Beirut, the Israeli military battleship that attacked our infrastructure, people's homes and civilians - look at it burning and will sink with dozens of Zionist Israeli soldiers.]

\section{The Jerusalem Post Report}

"Look at the warship that has attacked Beirut, while it burns and sinks before your very eyes," Nasrallah said. It was not clear whether he meant that the warship had already been attacked.

Although it is obvious from the source text that the Israeli warship had already been hit, still the Israeli newspaper reporter adds that it was not clear whether the warship had been targeted by the time of the speech. Nasrallah uses expressions like "now" and "look at it burning", clearly indicating that the Israeli battleship has been indeed targeted by his troops. This misreading added by the Israeli reporter may be caused by ideological and political views and/or the newspaper's pro-Israeli ideology. It may be aimed at underestimating the military capabilities of Hezbollah, reflecting a skeptical attitude 
towards the authenticity of Nasrallah's claims. It simply suggests that Nasrallah's claim has not been verified.

The political discourse of Hams and Hezbollah during the two offensives was an ideologically exotic discourse in the eyes of many Western and international media outlets that on occasions chose to made changes to the discourse through translation. For them, this discourse represented the discourse of the 'other', an exotic and alien Islamist discourse with ideas and values that need to be undermined. These translations choices were mainly inspired by ideological motives. At the centre of this process lies the translator's attitudes; misconceptions held about the Other's culture, ideology and religious convictions (Álvarez and Vidal 3). This can be traced in a report by The Telegraph (Butcher), on Khaled Mashal's speech aired on Aljazeera TV on 2 January 2009:

\section{Mashal's Statement}

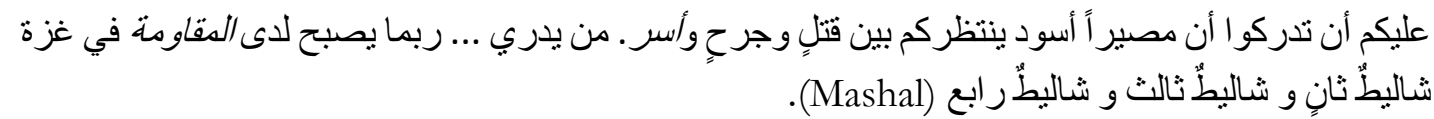

[You must realize that a black destiny is awaiting you, from death and injury to captivity. Who knows? ... the Resistance in Gaza may seize a second, third or fourth Shalit.]

\section{The Telegraph Report}

He also threatened that militants in Gaza could attempt to seize Israeli troops as hostages, as they did two years ago when the young soldier Gilad Shalit was kidnapped. "If you commit a foolish act by raiding Gaza, who knows, we may have a second or a third or a fourth Shalit," said Meshaal.

Three main interventions can be traced in the translation provided by The Telegraph in its report. The report uses the term "hostages" as an English equivalent to the ST term asr "captivity", adding a sentence that does not even exist in the source text: "as they did two years ago when the young soldier Gilad Shalit was kidnapped." The use of the verb "kidnapped" here in the report is also significant and suggestive. The report also drops the word al-muqawamah "the Resistance" in the translation and uses the subject pronoun "we" to refer to it. Only terrorists "kidnap" and take "hostages", and this is how the Telegraph report is trying to portray Hamas and present it to the target audience. The translator/reporter's choices here reflect an intention to delegitimize Hamas and present it as a terrorist organization, rather than a resistance movement. Hence came the translator's choice to delete the term "resistance" and replace it with the subject pronoun "we". Mashal believes that Hamas is a "resistance" movement, and the Israeli soldiers that Hamas manages to capture during the conflict are "captives", rather than "hostages". The influence of ideology manifests itself clearly in The Telegraph report. The interventions made by the translator/reporter seem to be aimed at undermining Hamas' identity as a resistance movement by manipulating Mashal's discourse and using a different set of vocabulary, apparently inspired by an ideological motive. 
Memri, is a US-based media organization that publishes selected videos from the Middle East with English subtitles. The media outlet has been accused of being biased to Israel as well as distorting the image of the Arabs and Muslims in general, especially in the way their published materials are chosen and subtitled. During the Lebanon War, Memri published selected parts of Nasrallah's statements. The selection and subtitling processes seem to consistent with ideological and political agenda. The following is an excerpt from Nasrallah's speech originally aired on Al-Manar TV on 3 August 2006. The excerpt was subtitled and broadcast by Memri and serves as an example:

Nasrallab's Speech

$$
\text { و وهمجية يتحمل مسؤوليته منذ اليوم الأول من هذه الحرب وما يجري حتى هذا اليوم، من قتل ومجازر وتدمير ووحشية }
$$

\section{Memri Subtitling}

What has happened since the first day of this war, and still happening even today - the killing, massacres, destruction, brutality, and barbarism - the ones responsible for all this, are first and foremost, Bush and his American administration.

As an American English-speaking media outlet, Memri primarily targets the American audience. By selecting this specific part of the speech, Memri seemingly aims at making its American audience aware that Hezbollah deals with the US and its administration as enemies. Therefore, the war that Israel waged against Hezbollah is also aimed at protecting and defending, not only Israel, but also the US and the Americans. This selection can be seen as an attempt to draw the US public support for Israel against Hezbollah.

Hatim and Mason argue that through mediation, translators "intervenes" in the discourse using four main tools: cohesion, transitivity, lexical choice and style-shifting (The Translator as Communicator 122). Influenced by ideology, news outlets intervened in the translation of the statements of Hamas and Hezbollah leaders during the reporting process. On many occasions, the translator of the discourse took advantage of their role as mediator and intervened in the translation process, making changes to the message embedded in the source text using tools such as lexical choice and style-shifting. A report published on the Israeli news website, Ynet News (Nahmias), on Mashal's speech aired on Aljazeera TV on 2 January 2009 serves as an example of such interventions in the translation/reporting process:

\section{Mashal's Statement}

$$
\begin{aligned}
& \text { نعم الظرف قاسِ في الضفة بسبب الاحتلال لكن المسؤولية أكبر ـ مسؤولية تاريخية أن ننتصر لغزة اليوم. بدأتم } \\
& \text { الانتفاضة الثالثة، نريد ترسيخها على الأرض كأمر و اقع (Mashal). }
\end{aligned}
$$


[Yes, the circumstances in the [West] Bank are harsh because of the occupation, but the responsibility is greater. It is a historic responsibility to support Gaza today. You have begun the third Intifada; we want to establish on the ground it as a fait accompli.]

Ynet News Report

\section{Mashal - Also called for resistance against Fatah.}

In this excerpt, Mashal urges the Palestinians in the Occupied West Bank to continue and cherish what he called a "third Intifada" clearly against the Israeli "occupation". This meaning is self-evident for anyone familiar with the political discourse of Hamas. The Israeli news outlet, however, has chosen to render the term "Intifada" as "resistance". The term "Intifada" has political and historical values, and its use bears a motivational function for the Palestinians. For Israel, a third Intifada represents a great challenge to the security of Israel and a substantial change of the game rules. Hence comes the lexical choice by the translator to overlook this term, trying not to help spread Mashal's message to the Palestinians. Additionally, the reporter inserts in the discourse two words, "against Fatah", which do not exist in Mashal's statement. This clearly aims to encourage a civil Palestinian conflict between Hamas and Fatah (a rival Palestinian faction that controls the West Bank) as this would ease the pressure on Israel. These interventions in the translation/reporting process have been carried out under the pretext of mediation and clarification.

Extrinsic managing suggested by Farghal (quoted in Shunnaq, "Monitoring and Managing in Radio News Reports" 104) is a key ideological strategy employed by media outlets in translating and reporting on the political discourse of Hamas and Hezbollah during the two conflicts. Since it would be difficult for media outlets to interfere in messages embedded in the discourse by merely monitoring the news material, using direct quotations translated from the original discourse, they tried to manage the embedded messages using indirect quotations, influencing the discourse in line with an ideological agenda. This often resulted in adjustments to the message of the original discourse to fulfil the media institutions ideological purposes. Fox News (Barzak and Teibel) employed this strategy of extrinsic managing in a report on Ismail Haniyeh's speech aired on 27 December 2008:

\section{Haniyeh's Statement}

$$
\text { الثعب الفلسطيني ... أصبح ... أكثر قوةًَ وأثندّ عزيمةً و أقوى إر ادةً وتمسكاً بحقوقه وثو ابته. }
$$

[The Palestinian people ... have become ... more powerful, determined, and strongwilled, holding onto their rights and principles even more than before.]

Fox News Report

In a speech broadcast on local Gaza television, Hamas' prime minister, Ismail Haniyeh, declared his movement would not be cowed. 
"We are stronger, and more determined, and have more will, and we will hold onto our rights even more than before," Haniyeh said.

As the then Prime Minister in Gaza, Haniyeh represented the whole Palestinian people, especially those in the Gaza Strip, and this role is evident in the source text. The reporter, however, chooses to replace the ST term "the Palestinian people" by the subject pronoun "we" in the directly quoted statement. The phrase "his movement" is also added to the indirectly quoted statement produced by the Hamas leader. The phrase "his movement" refers to Hamas. This use of managing as an ideological strategy to manipulate translation is consistent with the ideology adopted by Fox News, which is known for its far-right views, support for Israel and scathing criticism of Islamist ideology. The employment of the procedures of addition and replacement has ultimately resulted in a distortion of the original message intended by Haniyeh. The report clearly tries to depict the conflict in Gaza as a battle between Israel and Hamas only, and present Haniyeh as a representative of Hamas, rather than the Palestinian people as a whole. This can be seen as a delegitimizing tool aimed at undermining the popular legitimacy of Hamas and its leaders.

Other media outlets adopted the strategy of intrinsic managing in its translation of the political discourse of Hamas and Hezbollah, making alterations to sort mismatches between Arabic and English and explain ambiguities. A report published on Aljazeera English website which covered Nasrallah's speech aired on 26 July 2006 serves as an example:

Nasrallab's Statement

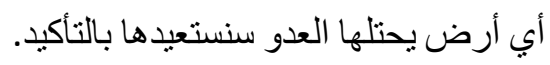

[Any territory the enemy may occupy we will definitely take back.]

Aljazeera Report

He [Nasrallah] said that the Shia Muslim group would take back any land Israel occupied.

Although the phrase "the Shia Muslim group", referring to Hezbollah, was not said by Nasrallah, the reporter chose to include it in the sentence, taking advantage of the freedom the use of indirect quoting allows. Although this form of managing suggests an alteration in meaning, it is not aimed at intentionally distorting the message embedded in the source text. This intervention is perhaps aimed at providing more information about the background of Hezbollah. It makes it easier for the Englishspeaking audience, who may be unfamiliar with the context of the conflict, to understand and analyze Nasrallah's discourse. This is likely to explain the motivation behind the translator choice here, given the established anti-Israeli editorial policy followed by Aljazeera.

\section{Conclusions and Findings}

As ideology governs all aspects of life including translation, news translators, editors, reporters and translated news agencies cannot be neutral. The translator cannot be an invisible, objective and transparent participant in the translation process. Rather, as a reader of the source text and an author 
of the target text, the translator proves to be an influential agent who leaves their fingerprints in every aspect of the translation process. The patrons' ideological beliefs can also be traced due to the authority they enjoy allowing them to impose their agenda on the translator's work. To achieve their agendas and serve their interests, media outlets reporting on the 2006 Lebanon War and 2008/9 Gaza War on many occasions employed certain ideological strategies and tools to intervene in the translation process.

This study has demonstrated that ideological views have governed the translation and reporting processes carried out by international, Western and Israeli news outlets which produced reports on political statement by the leaders of Hamas and Hezbollah during the 2006 Lebanon war and 2008/9 Gaza war. The ideological factor played a major role in determining the outcome of the translation process and the nature of reports produced by pro-Israeli news outlets such as Ynet and The Jerusalem Post. These materials were often ideologically biased to the Israeli narrative. Other Western and international news outlets such as Fox News, the CNN and The Telegraph tended to manipulate the discourse of the Hams and Hezbollah leaders, attempting to undermine the 'Other' and their Islamist alien values in line with certain ideological agendas.

Besides, due to the sensitivity of the discourse, media outlets chose to intervene in the discourse through comments which came out as titles, notes or introductory sentences to avoid criticism. Such media organizations did not seem to observe objectivity in their translation and presentation of the discourse. The original speaker's intention was not always carried over by the translators who interpreted the discourse in line with their previous knowledge which was ultimately ideological. Some media outlets like Memri followed a method of selection in which specific parts of the speeches were selected, translated and broadcasted to serve their ideological and political agenda. Media outlets also managed to intervene in the message embedded in the statements by employing the strategy of extrinsic managing, indirectly quoting the statements, and making significant changes at the lexical and stylistic levels. These changes often served the ideological and political agenda of the media institution concerned. The reports analyzed in this paper demonstrated a trend to delegitimize and criminalize Hamas and Hezbollah, by negatively presenting the two movements as terrorist and isolated from popular support.

Although this study has shed light on the manipulations and biased interventions carried out by Western and Israeli media outlets, it does not exclude or disregard a similar biased practice followed by anti-Israeli news outlets. In fact, it encourages future studies into the effect of Islamist and panArabist ideologies in reporting the translation of Israeli political discourse in the Arab media. This study suggests that ideology, whatever the ideology is, plays a crucial role in the decisions made by the translator, reporter and publishing media outlet in determining the outcome of the translation and reporting processes. 


\section{REFERENCES}

Abbas, Mahmoud. “Ar-Ra'̄̄s Fī Jinīn: Naḥnu Ma a as-Salām Al-'Adil Wa Al-Mufāw đ̣āt Wa Lākin Laysa Bi-'Ayyi Taman [President in Jenin: We Are with the Just Peace and Negotiations but Not with Any Price]." Wafa, 13 Oct. 2009, http://www.wafa.ps/ar page.aspx?id=t5Thoma526243268760at5Thom [accessed 5 September 2020].

Al-Majali, Sahar. "Al-'Orūba.. Bayna Salāḥ Ad-Dīn Wa Ardugian [Arabism, between Saladin and Erdogan]." Amman News, 5 June 2010, http://www.ammonnews.net/article/62122 [accessed 5 September 2020].

Álvarez, Román, and M. Carmen Africa Vidal. "Translating: A Political Act," in Translation, Power, Subversion, edited by Román Álvarez and M. Carmen Africa Vidal, Multilingual Matters LTD, 1996, pp. 1-9.

Barzak, Ibrahim, and Amy Teibel. "Israeli Assault on Hamas Kills More than 200." Fox News, 27 Dec. 2008, $\quad$ https://www.foxnews.com/wires/2008Dec27/0,4670,MLIsraelPalestinians,00.html [accessed 06 September 2020].

Blommaert, Jan, and Chris Bulcaen. "Critical Discourse Analysis." Annual Review of Anthropology, vol. 29, no. 1, 2000, pp. 447-66.

Butcher, Tim. "Hamas Threatens 'Black Destiny' If Israeli Soldiers Enter Gaza.” The Telegraph, 2 Jan. 2009, https://www.telegraph.co.uk/news/worldnews/middleeast/palestinianauthority/4077764/Ha mas-threatens-black-destiny-if-Israeli-soldiers-enter-Gaza.html [accessed 5 September 2020].

Calzada-Pérez, Maria, editor. Apropos of Ideology: Translation Studies on Ideology: Ideologies in Translation Studies. St. Jerome Publishing, 2003.

Eagleton, Terry. Ideology: An Introduction. Verson, 1991.

Fairclough, Norman. Analysing Discourse: Textual Analysis for Social Research. Routledge, 2003.

—. Critical Discourse Analysis: The Critical Study of Language. Longman, 1995.

—. Language and Power. Longman, 1989.

Fawcett, Peter. "Ideology and Translation," in Routledge Encyclopaedia of Translation Studies, edited by Mona Baker, Routledge, 1998, pp. 106-111.

Fowler, Roger. Language in the News: Discourse and Ideology in the Press. Routledge, 1991.

Ghazala, Hasan. “The Translator’s Dilemma with Bias.” Babel, vol. 48, no. 2, 2002, pp. 147-62. 
Haj Omar, Husam. "A Narrative Approach to Media Reporting of the Arab-Israeli Conflict 2000 2010: An Analytic Study." Forum: International Journal of Interpretation and Translation, vol. 17, no. 1, 2019, pp. 20-38, doi:https://doi.org/10.1075/forum.17014.haj.

Hatim, Basil, and Ian Mason. Discourse and the Translator. Longman, 1990.

—. The Translator as Communicator. Routledge, 1997, doi:10.4324/9780203992722.

Hatim, Basil, and Jeremy Munday. Translation: An Advanced Resource Book. Routledge, 2004.

Hermans, Theo. Translation in Systems: Descriptive and System-Oriented Approaches Explained. St. Jerome Publishing, 1999.

"Hezbollah Chief Threatens a Wider War." Aljazeera English, 26 July 2006, www.aljazeera.com/archive/2006/07/200849141727284582.html [accessed 06 July 2018].

"Hezbollah Leader Apologizes for Attack's Child Victims." CNN, 21 July 2006, http://edition.cnn.com/2006/WORLD/meast/07/20/nasrallah.interview/index.html?iref=alls earch [accessed 06 September 2020].

Huntington, Samuel P. The Clash of Civilizations and the Remaking of World Order. Simon and Schuster UK Ltd, 1996.

Kaiser-Cooke, Michele. "Translational Expertise: a Cross-Cultural Phenomenon from an InterDisciplinary Perspective," in Translation Studies: An Interdiscipline, edited by Mary Snell-Hornby et al., John Benjamin's Publishing, 1994, pp. 135-39.

Kress, Gunther, and Robert Hodge. Language as Ideologies. 2nd ed., Routledge, 1993.

Lefèvere, André. Translation, Rewriting and the Manipulation of Literary Fame. Routledge, 1992.

—. Translation/ History/ Culture. Routledge, 1992.

Marx, Karl, and Frederick Engels. The German Ideology. Lawrence and Wishart, 1970.

Mashal, Khaled. "Khaled Mashal's Speech." Aljazeera, 2 Jan. 2009, https://www.youtube.com/watch?v=QXn0twQIuC8 [accessed 05 September 2020].

Nahmias, Roee. "Mashaal: Launch Thrd Intifada." Ynet News, 27 Dec. 2008, https://www.ynetnews.com/articles/0,7340,L-3645251,00.html [accessed 05 September 2020].

Nasrallah, Hasan. Archive - The First Speech by Nasrallah. Al-Manar TV, 14 July 2006, https://www.youtube.com/watch? $\mathrm{v}=-$ yeMtw7XrnA\&list=PLEnRw69naN3WBfIfW1jNc4jLFgeIwdhef [accessed 20 August 2020].

- "Hizbullah Secretary-General Hassan Nasrallah Calls upon Arab Leaders to Promote Cease- 
TranscUlturAl, vol. 12.2 (2020), 19-38.

http://ejournals.library.ualberta.ca/index.php/TC

Fire in Meetings with the Americans." Memri, 3 Aug. 2006, https://www.memri.org/tv/hizbullah-secretary-general-hassan-nasrallah-calls-upon-arableaders-promote-cease-fire-meetings [accessed 05 September 2020].

. "Sayyid Hasan Nasrallah: Aljazeera Interview during the July War." Aljazeera, 20 July 2006, www.youtube.com/watch? ${ }_{\mathrm{v}}={ }_{\mathrm{OV} M H S g W z r T U}$ [accessed 01 August 2019].

- "Sayyid Hasan Nasrallah's Speech." Al-Manar TV, 26 July 2006, www.youtube.com/watch?v=TsDLnoDf1js [accessed 13 August 2019].

“Nasrallah Says Ready for 'Open War' with Israel." The Jerusalem Post, 14 July 2006, https://www.jpost.com/Israel/Nasrallah-says-ready-for-open-war-with-Israel [accessed 05 September 2020].

Neubert, Albrecht. "Translation, Interpreting and Text Linguistics." Studia Linguistica, vol. 35, no. 1-2, 1981, pp. 130-45, doi:10.1111/j.1467-9582.1981.tb00706.x.

- "Translation as Mediation," in The Cultural and Linguistic Barriers between Nations, edited by Rainer Kolmel and Jerry Payne, Aberdeen University, 1989, pp. 5-12.

Phillipson, Robert. Linguistic Imperialism. Oxford University Press, 2003.

Raymond, Geuss. The Idea of a Critical Theory: Habermas and the Frankfurt School. Cambridge University Press, 1982.

Robinson, Douglas. "The Invisible Hands That Control Translation.” QuadernsRevista de traducció, vol. 1, no. 1, 1998. pp. 83-87.

Roman, Denise. "Poststructuralism." Encyclopedia of Postmodernism, edited by Victor E. Taylor and Charles E. Winquist, Routledge, 2002, pp. 308-10.

Schäffner, Christina. "Skopos Theory." Routledge Encyclopaedia of Translation Studies, edited by Mona Baker, Routledge, 1998, pp. 235-38.

- "Third Ways and New Centres: Ideological Unity or Difference?" Apropos of Ideology, edited by Maria Calzada-Perez, St. Jerome Publishing, 2003, pp. 23-41.

Shunnaq, Abdullah T. "Monitoring and Managing in Radio News Reports," in Language, Discourse and Translation in the West and Middle East, edited by Robert de Beaugrande et al., John Benjamin's Publishing, 1994, pp. 103-14.

- Monitoring and Managing in the Language of Broadcasting and Newspaper. Dar Al-Amal, 1992.

Suleiman, Yasir. "Language and Political Conflict in the Middle East: A Study of Symbolic Sociolinguistic." Language and Society in the Middle East and North Africa: Studies in Variation and Identity, edited by Yasir Suleiman, Curzon Press, 1999, pp. 10-37. 
TranscUlturAl, vol. 12.2 (2020), 19-38.

http://ejournals.library.ualberta.ca/index.php/TC

Tahir-Gürçağlar, Şehnaz. "The Translation Bureau Revisited: Translation as Symbol.” Apropos of Ideology, edited by Maria Calzada-Perez, St. Jerome Publishing, 2003, pp. 113-130.

Van Dijk, Teun. A. Ideology: A Multidisciplinary Approach. SAGE Publications, 1998.

Venuti, Lawrence. Rehinking Translation, Discourse, Subjectivity, Ideology. Routledge, 1992.

. "Strategies of Translation." Routledge Encyclopaedia of Translation Studies, edited by Mona Baker, Routledge, 2001, pp. 240-44.

- The Translator's Invisibility: A History of Translation. Routledge, 1995, http://books.google.com/books?id=fHZjvOGO1MIC\&pgis=1.

Verschueren, Jef, editor. Language and Ideology: Selected Papers from the 6th International Pragmatics Conference. Vol1. International Pragmatics Association, 1999.

Yahiaoui, Rashid. Translation and Ideology. University of Salford, 2005. 